\title{
Article
}

\section{Challenges of an exhibit on nanoscience and nanotechnology}

\begin{abstract}
Sandra Murriello, Djana Contier e Marcelo Knobel
This article presents some of the challenges faced in developing an interactive exhibit on nanoscience and nanotechnology in Brazil. Presenting a scientific-technological area which is still in formation and which is little known by the population leads to a (re)consideration of the role of museums and science centers in the conformation and consolidation of scientific practice itself. Museographically, the exhibit deals with the challenge of making matter visible in an expression which is distant from the human perception. Some reflections are presented here on the option of musealization chosen which come from a broader evaluation of the exhibit.
\end{abstract}

\section{Introduction}

NanoAventura, which was developed in 2005 as part of the process of consolidation of the UNICAMP Exploratory Science Museum, is the first exhibit organized by this institution. ${ }^{1}$ The proposal was to create an interactive exhibit that would attract the interest of children and teenagers (9 to14 year-olds) to nanoscience and nanotechnology, generating a space for learning and entertainment. Within this perspective, NanoAventura was conceived as an invitation to explore the nanoscopic world in a playful fashion through images, music and simulations (figure 1.

A guide leads the hour-long visit, composed of videos and electronic games for a group with a maximum of 48 participants. A video, developed especially for the project, introduces the notion of scale, presents the fundamental aspects of nanoscience and nanotechnology, and shows the development of these areas in Brazil. In the next stage the group is divided into four smaller groups which move through the game stations. Three of the electronic games allow the manipulation of virtual objects, simulating laboratorial and industrial practices. The fourth game is a virtual tour, ${ }^{2}$ which invites the visitor to explore LNLS and UNICAMP research spaces. The experience finishes, once again returning to the larger group, with the presentation of a 3D video that visually recovers some of the previously presented ideas.

The development of NanoAventura has been evaluated since its initial phases [21]. Evaluation being a practice that has already been consolidated in the world's museums in the last decades, this tool was decided upon in order to constantly improve the products developed and to better accompany the processes and interactions that happen during the experience. Evaluations in museums can be classified according to objectives, paradigms of reference or the focus of interest and, according to various authors, their moments and phases receive different denominations and use various instruments [8],[23],[18],[20], For NanoAventura, the classification used as a reference is that proposed by the Audience Research Center of the Australian Museum (http://www.amonline.net.au/amarc/pdf/research/exhibition_evaluation.pdf), which considers front-end, formative, ${ }^{3}$ remedial and summative evaluation phases. In terms of methodology, questionnaires were the principal tools used, given that they are instruments which are appropriate for the proposed ends and for the conditions of the expository context. Interviews and observations were also used in order to collect data.

The objective of the front-end evaluation, carried out in the planning phase, was to identify the target audience's previous knowledge of contents to be dealt within NanoAventura. By using the dominant ideas as a point of departure, the results proved useful in the design of the proposal and the definition of a general script. The remedial evaluation, which took place with the general public and school-age public in 2005 during the beginning months of operation, showed the exhibit's positive points and problems and oriented decisions for improvement. The summative evaluation is still underway and plans to probe 

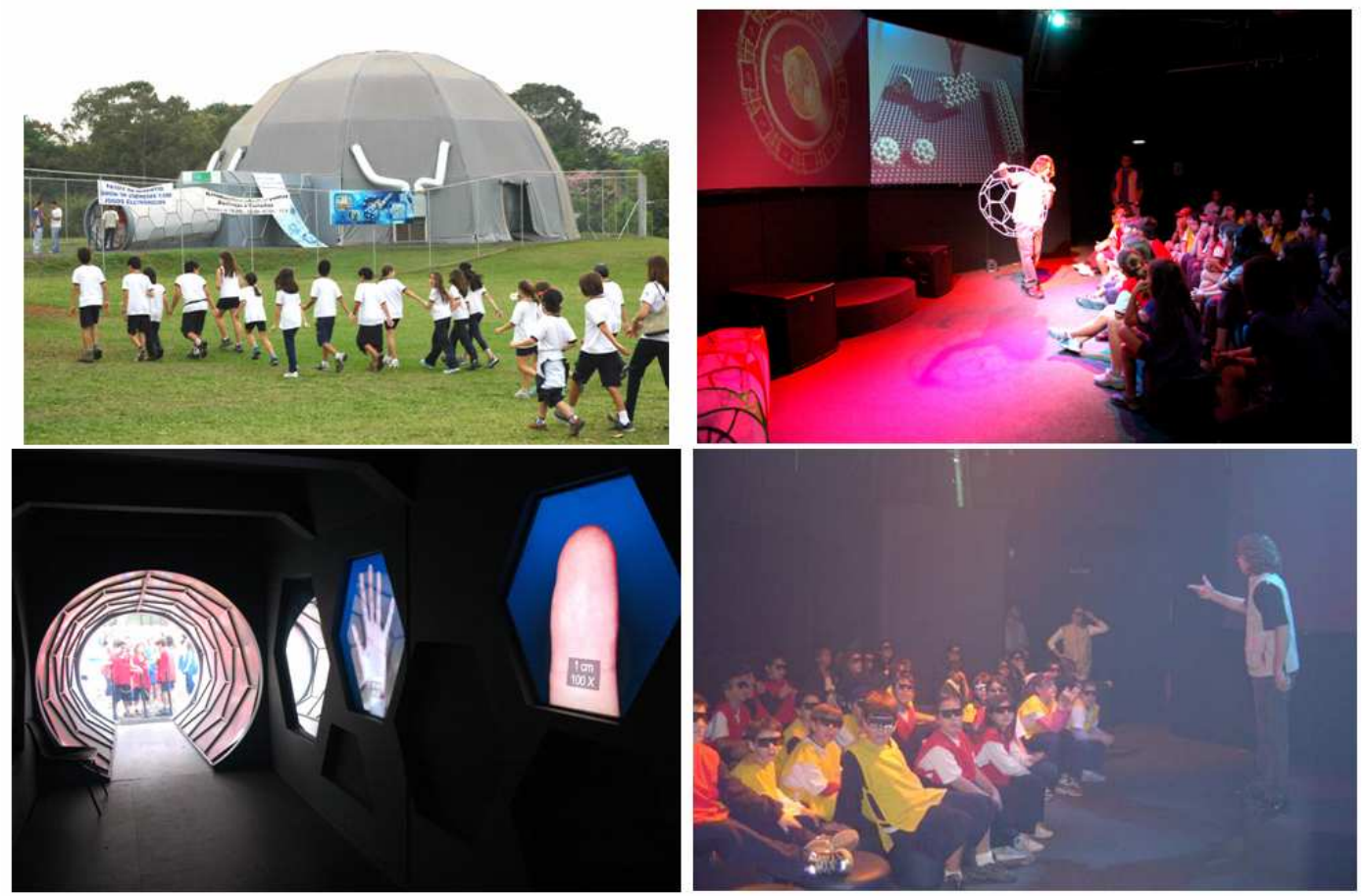

Figure 1. Some images of NanoAventura. Photos: Nelson Chinaglia (LNLS).

deeper into the analysis of the interactions of the public with the games and among partners, just as it also seeks to evaluate the affective, social and cognitive gains of the exhibit. There are also plans to study the analysis of the impact of the exhibit on a long-term basis, using the stimulated recall method [24] with groups that have already visited the exhibit.

This study highlights two of the main challenges faced in developing NanoAventura: the arousal of interest in an emerging science and a technology that are still distant from the everyday lives of the target audience, and the musealization of that which can not be seen by the naked eye. Some results of the evaluation of the museographic proposal used are also discussed.

\section{The first steps of an exhibit}

Nanoscience is recurrently referred to as a new science. However, the study of elements on a nanometric scale existed before being denominated as such. The development of appropriate instruments to observe and manipulate these elements had a strong push in the last two decades, leading to the emergence of a new technology that appears on the scene with its share of promises and uncertainties. Nanotechnology is the engineering of materials from atoms and molecules, making it possible to use the results of nanoscience in order to manipulate and reorganize nanoparticles and thus promote other combinations and, with this, elaborate new materials and devices. This is an emerging technology that is among the investment priorities in S\&T, which have been exponentially multiplied in the last decade [9] but which, according to research on this area in different countries, is still far from the concerns and interests of the largest part of the population.

Opinion polls done in the USA [4], the UK [1] and the comparison between Canada and the USA [5] show that people are still unfamiliar with these terms. Having some differences in the distinct contexts, the general attitude is of optimism in the face of new technological promises. Einseidel's study shows that these expectations are linked to improvements in the quality of life and, especially, questions of health. We do not have systematic information with regard to opinion in Latin American countries, where opinion and public perception polls are very recent and those that do exist [27], 26] do not contemplate this specific subject. However, even if a probable lack of factual information about new 
technologies is admitted, we believe that this does not impede the formation of attitudes because they fit into a broader relationship with science and technology [4][16]

Communication and education in nanoscience and nanotechnology in museums and science centers appear as a contribution to the still incipient science-technology-society dialogue. We know that exhibits on emerging scientific and technological themes are not a frequent practice in museums and science centers. The exhibition of scientific controversies is even less frequent. When this does exist, it is even more difficult to resolve [7]. We consider this a current path to be attended by institutions that try to contribute to the science-technology-society dialogue and that should redefine their role as mere transmitters of scientific principles in order to be converted into spaces of reflection and debate. However, this transformation requires a more in-depth process that will lead to the reversion of the traditional role of scientific communication being based on a deficit model [29]. This, as Hooper Greenhill [19] shows, has also been the dominant model in science museums.

Being aware of the distance of the topic for the target audience, we question, in the front-end evaluation, about the previous ideas and knowledge that are linked to nanoscience and nanotechnology [21]. Less than $20 \%$ of the sample of 72 students from the Campinas and São Paulo public and private educational systems were familiar with the words nanoscience and nanotechnology. In this same sample, no one dared to define these terms. Moreover, terms which are part of a school curriculum and which are key concepts to the interpretation of this area, such as atom, molecule and cell, appear as vague definitions that are scientifically incorrect and even inverted. These terms appear, at times, linked to the idea of component, fraction, constituent piece of something larger. At the same time, however, the dominant idea is that matter is made up of smaller pieces of itself. These results alerted us to the difficulties of a conceptual comprehension of nanotechnology, raised concerns about the concept of matter, and helped to define the thematic foci to be dealt within the exhibit.

The difficulties of presenting a science based on that which is not seen by the naked eye in an exhibit appeared as one of the museographic and communicational challenges. This same concern had been brought up by the evaluation team of the "It's a nanoworld" exhibit, ${ }^{4}$ developed in the USA [3]. Aimed at children ages 5 to 8, this exhibit's goal was to present the nonvisible universe from macro to micro and from there to nano, taking into consideration the notion of scale as one of the greatest obstacles for the understanding of nanoscience. The front-end evaluation of NanoAventura also showed that the target audience's idea of small was quite distant from that of the nanoscopic universe. The smallest objects recognized were objects not visible to the naked eye (48\%), of which $83 \%$ were biological structures (such as bacterias, cells or microbes in general), with only $17 \%$ of responses citing basic structures such as atoms or molecules. On the other hand, $33 \%$ of responses identified objects visible to the naked eye, especially insects such as fleas and ants, as the smallest structures known. Thus the microscopic universe linked to biology appeared as the most significant and as a possible entryway for contents that are distant from the perception of children and teenagers.

The scale in which nanoscience and nanotechnology operate demands images from specialized and delicately manipulated instruments. The object's image and the simulations are the forms of approximation and experimentation in the nanoscopic world. What, then, is the possibility of "musealizing" these objects? Various authors [10],[28] defend that the "authenticity" of the objects their materialness - constitutes the differential characteristic of museums. Without any doubt, the direct contact with material objects attracts attention, evokes emotions, and stirs the visitor, characterizing the museal experience. Even though agreeing with this position, ${ }^{5}$ we ran into difficulty in the planning of the exhibit that was directly linked to the nature of our museal object. How to set up an exhibit with real nano-objects? The proposal of developing a virtual representation of these manipulatable objects by means of multimedia resources seemed to be an option that offered an expository solution and that would serve to simulate a context similar to that of laboratories, thus avoiding having to deal with the question through the use of science fiction elements.

On the other hand, the use of a virtual language that was nearer to the target audience challenged us to develop an innovative expographic approximation on this topic. As Hall [11] affirms, interactive virtual proposals have come to science museums to stay. They are entertaining and relate to the daily life of a young audience. Without attempting to affirm the existence of a homogeneous "net generation", and recognizing the differences in approximation and enjoyment of this language, as well as preferences 
according to gender [12], we believed that this would be an easily-accessible language and one that challenged the learning-entertainment binomial which is in debate in science museums. Several studies defend the development of new cognitive abilities in assiduous videogame players, but there is still a need to better understand how this language, and the type of interactivity that it proposes, helps the learning of scientific concepts. In addition, research in museums has already shown that the fact of an apparatus, device or module being interactive or hands-on, does not guarantee that it will be minds-on, and much less - in the words of Wagenberg [28] - hearts-on. How the interactiveness of electronic games contributes to learning is still an open question. The incorporation of games in the exhibit was also recognized as an opportunity to contribute to the field of study of the interaction that occurs in the exhibition of these objects. The incorporation of these resources allows a more in-depth probe of research on the use of multimedia resources in museal exhibits [14]. This continues to be evaluated and we present the preliminary results in this study.

\section{Game evaluation}

The four games were especially developed for the exhibit, and their aspect fits into the environment of strong visual and technological appeal that was chosen for the exhibit table 1). These games make use of joysticks and buttons, resulting in easy manipulation for an audience that is already familiar with the use of domestic electronic games. In the remedial evaluation, carried out in the first months of the exhibit, we detected that over $85 \%$ of visitors - of which more than $65 \%$ were students from public and private institutions - were regular or assiduous players. This previous knowledge was important not only to show the adaptation of the selected proposal to the target audience, but also to be able to evaluate the games. Ergonomic problems and problems of playability were detected in the remedial evaluation and resolved during the actual functioning of the exhibit. Because of a mere lack of time, a formative evaluation was not developed for these games. This would have permitted the detection of some of these problems before opening to the public. This fact only confirms the importance of this practice and its consideration starting in the general planning phase.

As it has already been shown in other interactive exhibits, multiple-user games are used for more time than are individual games. Moreover, they favor social interactions [15]. NanoAventura's games were designed as team games - of up to 12 people - with a collaborative nature, permitting the users to have control of their individual and collective scoring. During the experience competition is stimulated among the different groups only as a way of improving the development of the tasks and always pointing out that there are no winning teams.

The remedial and summative evaluations, which are still underway, provided, among other things, information on the advantages and disadvantages of the games that were developed. The results obtained in the remedial phase allowed us to introduce some technical changes and improvements, which we are still evaluating in terms of effectiveness.

Based on the computer game categorization developed by Malone and Lepper [22] and on that of Perry's [22] motivating exhibits, we created our own categorization to evaluate the games:

1. Challenge: stimulus to surpass one's own performance

2. Curiosity: generation of questions and doubts about the topic

3. Cooperation: collaborative social interactions in pairs and with the monitor

4. Competition: stimulus to surpass others

5. Playability: clarity of the proposal and the workings of the game in the context of the exhibit

6. Meaning: meaningful topic/close to the visitor's experience

7. Ergonomics: comfort for carrying out the task 


\begin{tabular}{|l|l|}
\hline Nanomedicine & $\begin{array}{l}\text { At this station, the players have to prepare and } \\
\text { Objective: in teams, save sick cells with } \\
\text { medication that is covered with a layer of } \\
\text { nontoxic material. }\end{array}$ \\
$\begin{array}{l}\text { player should choose ant cover the medication, } \\
\text { before sending it into the interior of the cell. } \\
\text { Those who discover which of the medications is } \\
\text { the most efficient has to tell their teammates in } \\
\text { order to save more cells. }\end{array}$ \\
\hline
\end{tabular}

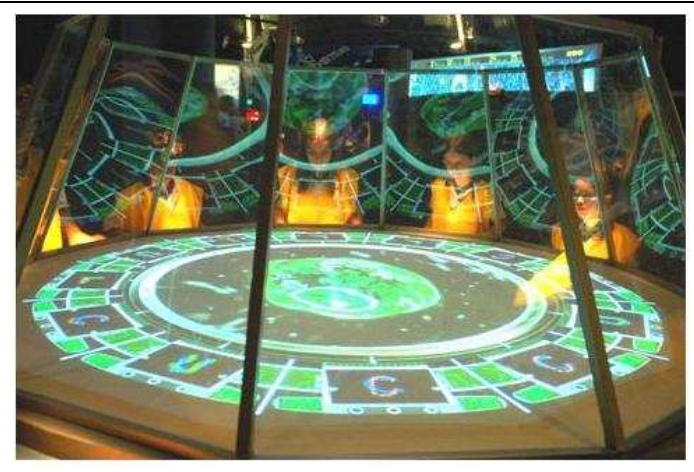

\section{Virtual tour}

Objective: to become familiar with the environments in which nanoscience and nanotechnology are worked with.

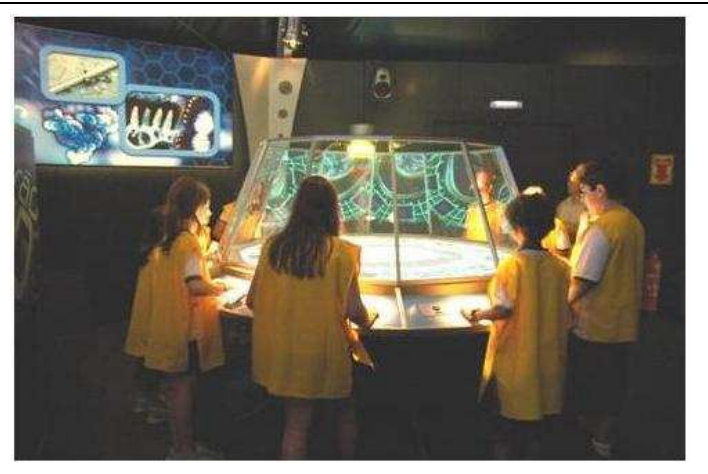

This is more of an exploratory environment developed with game technology than actually a typical videogame. Here, each visitor is part of a team of scientists and collaborates with research tasks at LNLS, at UNICAMP and in the knowledge room, an environment created for this game.

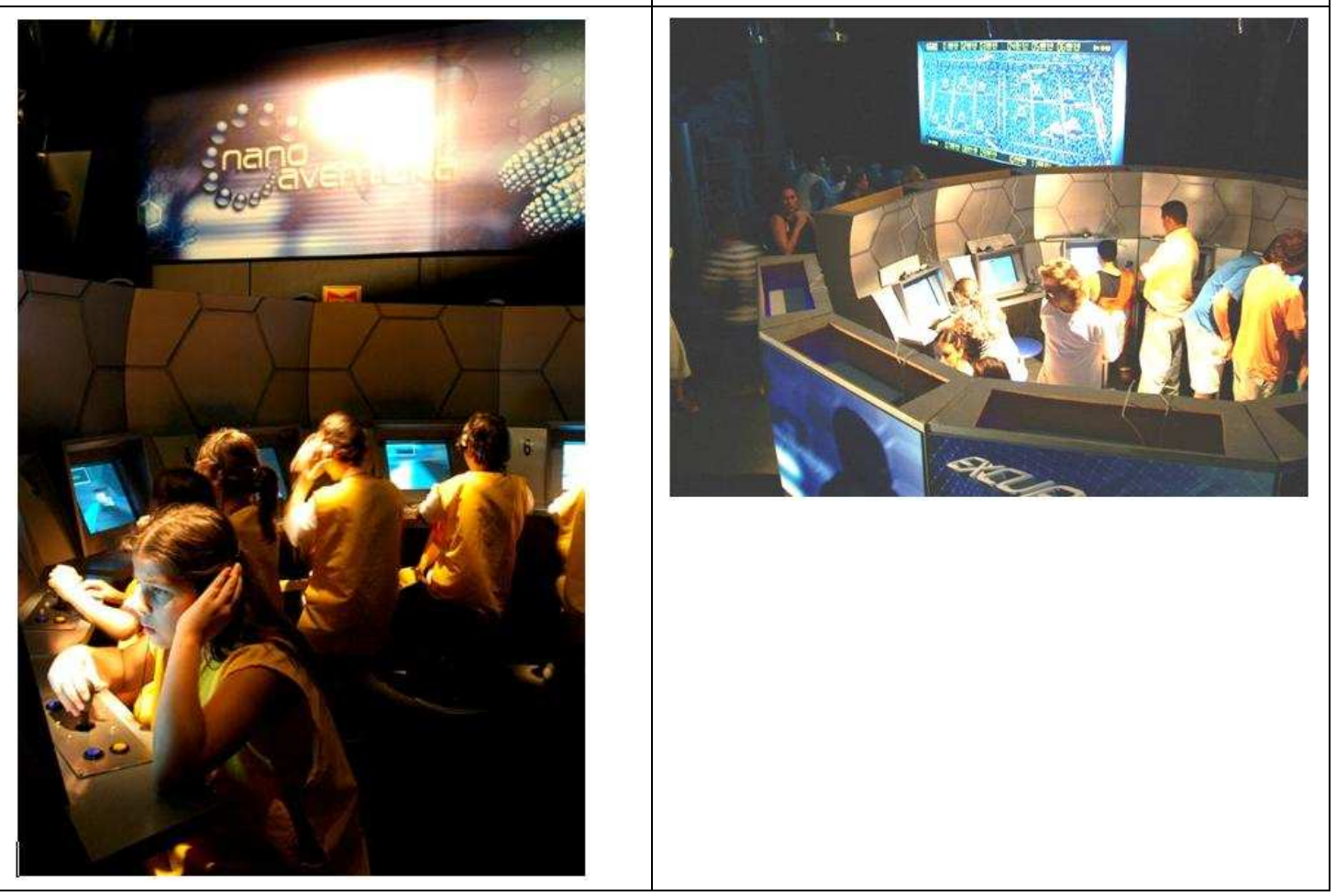




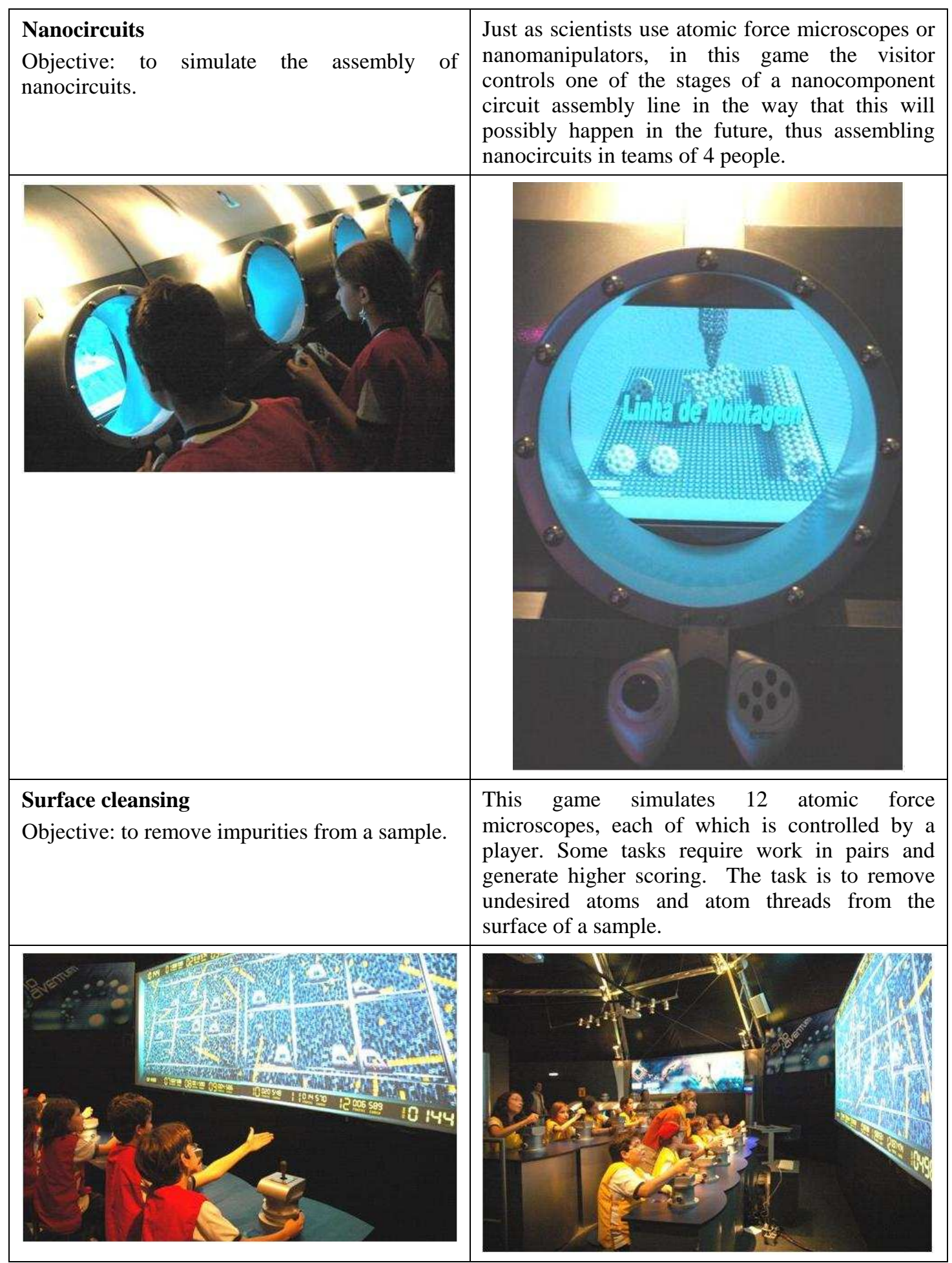

Table 1. Description of the NanoAventura electronic games, with illustrational images. Photos: Nelson Chinaglia (LNLS). 


\begin{tabular}{|l|l|l|l|l|}
\hline & Nanomedicine & $\begin{array}{l}\text { Surface } \\
\text { Cleansing }\end{array}$ & Assembly Line & $\begin{array}{l}\text { Virtual } \\
\text { Tour }\end{array}$ \\
\hline 1. Challenge & high & high & high & high \\
\hline 2. Curiosity & high & high & high & high \\
\hline 3. Cooperation & high & high & high & low \\
\hline 4. Competition & high & high & medium & low \\
\hline 5. Playability & good & good & regular & regular \\
\hline 6. Meaning & high & low & low & medium \\
\hline 7. Ergonomics & Regular - height /sound & Regular - sound & Regular-sound & Regular - \\
\hline
\end{tabular}

Table 2. Evaluation of the NanoAventura games.

These criteria were evaluated on a good/regular/bad or high/medium/low scale. The results of this evaluation (table 2) allow us to see correct aspects and problems of each game and the set of games as a whole. In this way we can affirm that the games attract curiosity and challenge their users in a way that holds their attention within the time available. In general, there is the complaint that the time is too short. People want to play longer. As Studart [25] points out, several authors show that the involvement with the task, in such a way that the notion of time is "lost," is a requirement for motivating exhibits. Curiosity, challenge and playability are intrinsically linked. In the remedial phase, the virtual tour presented various playability problems. The game's lack of objective and the lack of clarity in the definition of the task to be carried out were pointed out by visitors who quickly lost interest in the proposal. Because of these results, the game was reformulated, improving the audience's response as the game managed to hold their attention the whole time. However, we are detecting that some difficulties still remain with regard to the clarity of the presentation of the proposal. These aspects should be improved in the next phase.

The double nature of the games - competitive and collaborative - is worth mentioning. Competition is a necessary characteristic in order for the game to be challenging. Collaboration intends to stimulate attitudes of intra-team cohesion by proposing a common task. This collaboration presents differing levels of interaction with partners. In the surface cleansing, for example, this mutual collaboration is even more reinforced, generating yet another challenge in the game. The visualization of the game score stimulates competition with other teams and reinforces internal bonds. A common problem in all of the games was the initial explanation and the interference caused by the sound of other games. These problems were partially solved with the use of headphones and a dynamic explanation of the game that was reinforced by the monitors.

It is also worth noting that there was greater acceptance of the Nanomedication game, presenting better results in all of the categories evaluated. We highlight that this game is the only one that presents the application of nanotechnology in the field of health, a topic which is nearer to the visitors' reality. Some studies [16] have shown that the acceptance of new technologies is linked not only to a cognitive response but also to an affective response. It has also been shown that the resignification of an exhibit's objects is strongly influenced by previous knowledge and interests [6] It is interesting to think that, even with probable difficulties in defining a cell, the concepts of medication and disease cure are clear and appealing. This makes us believe that nanobiotechnology could be a good entryway, with greater appeal to a diverse audience.

We prove that control of the situation [22], in our case game language, is a prerequisite for benefiting from the exhibit. In adults who do not dominate the language, inhibition or frustrated participation is observed in taking part in the game stage. The obstacle is in the interaction with the equipment. In this case, the experience of the visit as a whole is affected. The attitude of maintaining distance in the game stage was frequently observed in teachers accompanying their classes. In a similar fashion, in the questionnaires that were answered during the remedial evaluation, those who declare that they never play any type of game are some of the teachers from the visiting school groups. This raises doubt about how beneficial the experience was as a whole for teachers and students. On the other hand, we have observed that in family groups, this lack of dominion on the part of the adults leads the children to explain the workings and the basic rules of the use of the equipment to their parents or adult relatives (figure 2). This 


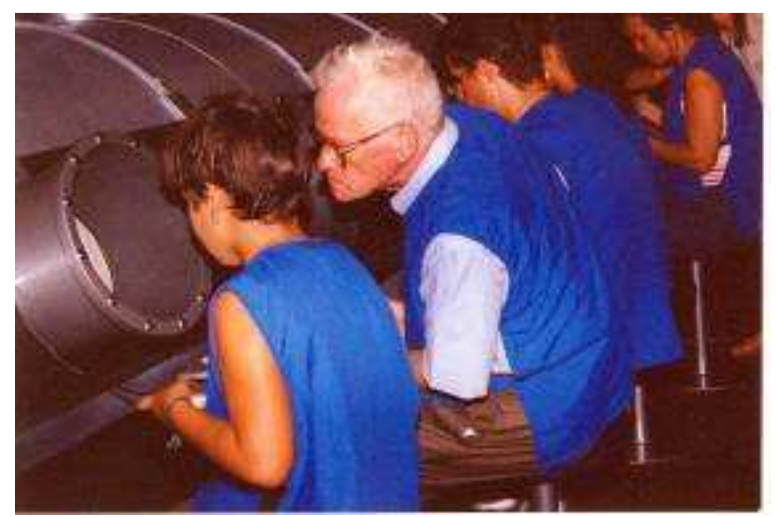

Figure 2. Child teaching an older person the nanocircuit assembly game during the NanoAventura exhibit in Rio de Janeiro.

interaction is interesting, for it shows an inversion of the already recognized attitude of parents "teaching" their children within the museum context [17],

\section{Some conclusions}

The evaluations carried out reveal that the use of games in the exhibit operates as a fundamental factor for attracting and entertaining the target audience. For a public untrained in this language, access proves to be difficult. We believe that interaction with games still offers the possibility of a more in-depth analysis in order to draw us nearer to an interpretation of the educational potential. However, we know that games should be analyzed in the context of the exhibit and of the visit as a whole. In this sense, we already have some results that show cognitive gains in the visit and that satisfy some of our basic proposals. The approximation of the nanometric scale and the identification of nanoscience and nanotechnology as the study and manipulation of matter at this scale appear as concepts incorporated in the visit in our remedial and summative evaluations. We also see a greater appeal in relation to questions of biology and health, leading us to think that future actions could be focused on these topics as a way of drawing the topic nearer to the public. There is still a need to advance in our study in order to better understand the affective gains, but we do have the experience of an enthusiastic response and of some visitors who returned to NanoAventura with relatives and friends.

Through NanoAventura we have seen the importance of the museographic proposal in order to generate immersion experiences, the central role that interaction with others has within the exhibit - in the games as well as the experience as a whole, and, we highlight, the influence of previous knowledge and interest in order for the individual to benefit from the proposal presented. The interaction of these factors produces an experience, leaves a remembrance of the visit, which can be taken advantage of and complemented in the medium and long term, depending on the stimuli that are offered.

\section{Some pending questions}

There is a debate on the type of learning that occurs in museums based on different educational concepts, on the multiple styles of learning and on the forms of mediation and evaluation. To think of learning in informal settings requires a destructuring of the term, a breaking up of our most consolidated conception of learning linked to school curriculum. We understand that, as is pointed out by several authors [6], learning in the informal context should be understood and analyzed outside of this paradigm. The "learning of free choice," as defined by Falk \& Dierking [6], better characterizes that which happens in interactive science museums. The contextual model of learning developed by these researchers proves to be useful in analyzing which are the specific characteristics of a museal experience such as that of NanoAventura, in which the physical, socio-cultural and personal contexts relate to one another over time. 
A point to be further investigated is the relationship between learning and entertainment. Some authors show that this differentiation is more of a concern for exhibit idealizers than for the visiting public itself. The search for an experience with an educational basis implicitly has an agenda that influences benefiting from the experience. With regard to NanoAventura, we still need to question the motives of visits in the case of school outings, which are the majority of the cases. We need to better understand the expectations of the visitors and, in the case of teachers and students, know if there is any prior preparation and/or follow-up work in the classroom and/or through the complimentary material and resources provided. ${ }^{6}$ This area provides a space for research that will allow for the better understanding of the expectations and the results of the visit in the long term as well.

Taking advantage of the virtual in the museum's own space is yet another aspect that raises our interest in a new type of museal relationship in the same way that Hawkey ([13], p.4) affirms, "A new set of relationship is emerging, between objects, learners and digital technology, in which museums are, above all, places of exploration and discovery. In the museum of the future, distinctions between real and virtual, already blurred, will matter even less as both museums and learners better understand the process of inquiry and of learning itself." As has been pointed out, games are a source of complimentary research, opening a path that is still little explored by museal institutions.

Finally, we would like to point out that an exhibit on an emerging scientific and technological area in which the public is forming its representation seems to us to be a good opportunity to work from the initial phases on the science-technology-society relationship. In the words of Einsedel [5], "The technology is also in its early days. What better time to engage different publics than the present, when technology is in its more flexible form?"

Translated by Robert C. Garner

\section{Bibliography}

[1] A. Anderson, A. Stuart, A. Petersen, C. Wilkinson, The framing of nanotechnologies in the British newspaper press, Science Communication, 27 n.2 (2005) p.200-220.

[2] Australian Museum. Audience Research Centre, Exhibition evaluation. Disponível em: http://www.amonline.au/amarc/pdf. Accessed on: 29 Nov. 2004.

[3] C. Batt, A. Waldron, C. Trautmann, It's a nanoworld: a study of use. Findings from a summative study, June, 2004. Available at: eduinc.org/ItsaNanoWorldSummativeStudy.pdf. Accessed on: 24 April, 2006.

[4] M.D. Cobb, Framing effects on public opinion about nanotechnology, Science Communication 27 n.2 (2005) p.221-239.

[5] E. Einsiedel, In the public eye: the early landscape of nanotechnology among Canadian and U.S publics, Azojono, Journal of nanotechnology on-line (2005). Available at: www.azonano.com/oars.asp Accessed on: 5 June 2006.

[6] J. Falk, D. Dierking, Learning form museums visitors experiences and the making of meaning. Walnut Creek, CA, Altamira Press (2000).

[7] S. Macdonald, R. Silverstone, Science on display: the representation of scientific controversy in museum exhibitions, Public Understanding of Science 1 (1992) p.69-87.

[8] R. Korn, Introduction to evaluation: theory and methodology, In: N. Bery, S. Mayer, (Orgs.) Museum education: history, theory and practice, Reston, Virginia: The National Art Association, (1989) p.219-238.

[9] L. Stephens, News narratives about NanoS\&T in major U.S. and Non-U.S. Newspapers, Science Communication, 27 n.2 (2005) p.175-199.

[10] G. Leinhardt, and K. Crowley, Objects of learning, objects of talk: changing minds in museums. Disponível em kevincrowley.com/leinhardtcrowley.pdf. Accessed on: 29 Nov. 2004.

[11] J. Hall, Telling old stories new ways: using technology to create interactive learning experiences, Washington: Smithsonian Center for Education and Museum Studies. 2004 Available at: http://museumstudies.si.edu/hall.pdf Accessed on: 25 Aug. 2006. 
[12] A. Mc Farlane, A. Sparrowhawk and Y. Heald, Report on the educational use of games: an exploration by TEEM of the contribution which games can make to the education process, Teem: Cambridge, 2002. Available at: www.teem.org.uk Accessed on: 20 Aug. 2006.

[13] R. Hawkey, Learning with digital Technologies in museums, science centres and galleries. Futurelab series. Report 9 (2004). Available at: www.futurelab.org.uk. Accessed on: 15 June 2006.

[14] C. Heath, D. vom Lehn, J. Osborne, Interaction and interactivities: collaboration and participation with computer-based exhibits, Public Understanding of Science 14 (2005) p.91-101.

[15] J. Kennedy, User friendly:hands-on exhibits that work, Washington, D.C., Association of Science Technology Centers. 1990.

[16] C. Lee, D. Scheufele and B. Lewenstein, Public attitudes toward emerging technologies, Science Communication 27 n.2 (2005) p.240-267.

[17] P. McManus, Is teh company you keep...the social determination of learning behaviour in a Science Museum, The Interntional Journal of Museum Management and Curatorship 6 (1987) p.263-270.

[18] G. Hein, Learning in the Museum. Routledge, London, 1998.

[19] E. Hooper-Greenhill, Museum and their visitors. London:Routledge. 1994.

[20] T. Moussouri, A context for the development of learning outcomes in museums, libraries and archives, (2002). Available at: http://www.mthe.gov.uk/documents/insplearn_wp20030501.pdf. Accessed on: 25 Sept. 2004.

[21] S. Murriello, D. Contier, Relatório de avaliação da NanoAventura, June 2005, Available at: www.nanoaventura.org.br

[22] D. Perry, Designing exhibits that motivate, In: ASTC. What research says about learning in science museum? Washington, D.C., ASTC 2 (1994) p. 25-29.

[23] C.G. Screven, Uses of evaluation before, during and after exhibit design, ILVS Review 1 n.2 (1990) p.36- 66.

[24] J. Stevenson, The long term impact of interactive exhibits, International Journal of Science Education 13 n.5 (1992).

[25] D. Studart, Famílias, exposições interativas e ambientes motivadores em museus: o que dizem as pesquisas?, In: Avaliação e estudos de públicos no Museu da Vida. Rio de Janeiro: Caderno do Museu da Vida, (2003) p.33-42.

[26] C.A. Vogt. (coord), M. Knobel, R. Almeida, S. Pallone, Y. Castelfranchi, Percepção Pública da Ciência: uma revisão metodológica e resultados para São Paulo, In:FAPESP. Indicadores de ciência, tecnologia e inovação em São Paulo, 1 cap 12 (2004), São Paulo: Fapesp, 2005.

[27] C.A. Vogt, C. Polino, Percepção pública da ciência: Resultados da pesquisa na Argentina, Brasil, Espanha e Uruguai. Campinas, SP: Editora da Unicamp, Campinas, 2003.

[28] J. Wagensberg, O museu "total”, uma ferramenta para a mudança social, História, Ciência, Saúde-Manguinhos, Rio de Janeiro, Brasil, 12 (2005) p.309-321 (Museu e Ciências. Suplemento. Dossier 4 Congresso Mundial de Museus e Centros de Ciência).

[29] J. Ziman, Not knowing, needing to know, and wanting to know, In: B. Lewenstein, (Ed.) When Science meets the public. Washington, D.C., American Association for the Advancement of Science (AAAS) 1992.

\section{Notes and references}

\footnotetext{
${ }^{1}$ The UNICAMP Exploratory Science Museum began to be planned in 2003 and was officially inaugurated in November, 2006. NanoAventura was opened to the public in April, 2005 in the city of Campinas, state of São Paulo, and in its first year of operation was exhibited in the cities of Rio de Janeiro (RJ), Porto Alegre (RS), São Paulo (SP) and Campinas (SP), with over 25,000 visitors. The event took place in partnership with the National Sincrotron Light Laboratory (LNLS) and the Sangari Institute. It received financial support from the Vitae Foundation, the State of São Paulo Foundation for Research Support (FAPESP) and the patronage and support of other partners.
} 
${ }^{2}$ In the classification of digital technologies that was realized by Hawkey (2004, p.8) and edited by Futurelab (UK), the first three would be games, while the virtual tour would correspond to a simulation. For the purposes of this article, we will call them all electronic games without distinction.

${ }^{3}$ In the case of NanoAventura, for reasons of time, it was not possible to carry out a formative evaluation that would have provided useful information for operational changes that were postponed to later phases.

${ }^{4}$ This $3000 \mathrm{~m}^{2}$ exhibit was developed by The Nanobiotechnology Center, of the Sciencecenter, Ithaca, New York, and Painted Universe Inc.

${ }^{5}$ We point out that on-line museums deserve another discussion.

${ }^{6}$ See, for example, the didactic material designed for teachers, "NanoAventura na Escola," available for download in pdf format at http://www.nanoaventura.org.br.

\section{Authors}

Sandra Murriello, Laboratório de Estudos Avançados em Jornalismo (Labjor), Núcleo de Desenvolvimento da Criatividade (Nudecri), Universidade Estadual de Campinas (UNICAMP)., Postdoctorate researcher. PhD in Sciences (Geosciences education)- UNICAMP, Brazil. Biologist (ecology) Universidad Nacional de La Plata, Argentina. E-mail: sdrnano@yahoo.com.br.

Djana Contier, Museu Exploratório de Ciências, Universidade Estadual de Campinas (UNICAMP), Master of science student - Science and Mathematics education - Education Faculty - Universidade de São Paulo (USP). Physicist - Instituto de Física USP, Brazil. E-mail: djanacontier@ig.com.br.

Marcelo Knobel, Laboratório de Estudos Avançados em Jornalismo (Labjor), Núcleo de Desenvolvimento da Criatividade (Nudecri), Universidade Estadual de Campinas (UNICAMP) and Museu Exploratório de Ciências, Universidade Estadual de Campinas (UNICAMP)., Associate Professor, Instituto de Física Gleb Wataghin (IFGW), Universidade Estadual de Campinas. PhD in Physics - UNICAMP. Works with science popularization and is the Director of the Science Museum of UNICAMP. E-mail: knobel@ifi.unicamp.br. 